\title{
Spurious growth in German output data, 1913-1938
}

\author{
ALBRECHT RITSCHL \\ Humboldt University of Berlin and CEPR, School of Business and Economics, \\ Humboldt University, Spandauer Strasse I, D-IOI78 Berlin
}

\section{Introduction}

Stagnant levels of output and incomplete recoveries in the interwar business cycle have received fresh attention in recent work. Building on the work of Borchardt (I99I [1979]), Fisher and Hornstein (200I) calibrate an augmented RBC model of Germany's interwar economy. They find that sluggish productivity combined with high wage costs explain the depth of Germany's interwar depression. In the very different context of a dynamic Phillips curve, Dimsdale et al. (2004) arrive at the same conclusion. Cole and Ohanian $(1999,2002)$ find that output in Great Britain and the United States failed to recover to historical trends after the Great Depression. Beaudry and Portier (2002) find that the labour policies of the Popular Front government contributed to stagnant output levels in France during the I930s. A common perspective shared by these papers is that productivity growth was already low during the I920s and failed to recover to trend before World War II.

At least on some accounts, German data appear to be an exception. The most widely accepted series, compiled by a group around Hoffmann et al. (1965) from reconstructed data, shows an impressive increase in national product and industrial output during the late I920s and again after 1933. Growth of the manufacturing series is largely driven by the metal-processing industry, whose output as estimated by Hoffmann grew by 70 per cent between 1913 and 1929 and more than tripled during the whole period from I9I3 to I939. As Germany was the world's second largest industrial economy at the time, this apparently more favourable performance seems important, all the more so as it contrasts starkly with its rather less favourable political history at the time. Can a driving force be identified that explains the rapid recovery exhibited in the data? Was Germany an international growth engine? Did Germany make a difference?

This article argues that growth in German output data between 1913 and 1938 is largely spurious. It arises from what would seem a reasonable assumption in constructing the data, the constancy of factor shares over time. Hoffmann et al. (1965) estimated output in the German metal-processing industry (that is, machine building, automobiles, shipbuilding, electrical 
and optical industries) from wages and employment, assuming a constant wage-income ratio. This assumption appears innocuous under competitive conditions and a Cobb-Douglas production function, which together yield constant factor shares. It is equally harmless under more general constant returns to scale technologies along a steady-state growth path (in which the profit rate and the capital-output ratio remain constant, again implying constant factor shares). It is, however, not innocuous and prone to introduce bias as soon as factor shares change systematically.

Recent work by Bentolila and Saint-Paul (2003) on wage bargaining in the presence of a CES production technology has highlighted the sources of the fluctuations in factor shares over the business cycle. If the elasticities of factor substitution differ from I, and trade unions and employers bargain over wages and employment jointly, profits will absorb the productivity shocks. As the employment adjustment channel is shut down, the income shares of capital and labour are affected. Any output or income estimate that is based on the assumption of constant factor shares is then likely to mismeasure output.

Indeed there is ample international evidence of adverse productivity shocks, increased trade union power, and rising wage shares after World War I. In an influential paper, Borchardt (I99I [1979]) noticed on the basis of different data that unit labour costs in Weimar Germany during the late I920s were far above long-term trends. His claim was that these abnormally high wages contributed to the particular severity of the Great Depression in Germany. This generated almost I 5 years of controversy among German historians - see Spoerer (1994) for a review. Employing contemporaneous semi-official income and product data for Germany, Broadberry and Ritschl (1995) examined comparative evidence for Britain and Germany and found patterns of wage pressure during the 1920 s to be very similar across both countries. In both countries, a surge in trade union membership, collective wage bargaining and the eight-hour day appeared to have tilted the functional distribution of income in favour of labour.

The German economy indeed exhibits very much the same patterns as elsewhere, provided output and income are measured properly. The present article will show that discrepancies between the official data and Hoffmann's index mostly disappear once output in metal processing is estimated independently of factor incomes. The rest of this article is structured as follows. Section 2 discusses the basic elements of Hoffmann's index in more detail. Section 3 focuses on an attempt of Balderston (I993) to reconstruct Hoffmann's estimate of metal-processing output, and compares these with contemporary data from both official and industry sources. Section 4 constructs a new index of metal-processing output from these contemporary sources and inserts the results into Hoffmann's index of industrial production. Section 5 goes one step further by tracing the effects of this correction on Hoffmann's output-account estimate of German net 
domestic product, and Section 6 concludes with some remarks on possible avenues for future research.

\section{Hoffmann's index of industrial production: basic concepts}

Existing data on manufacturing output for interwar Germany come from two sources. Contemporary statistics were compiled by the Statistical Office (Statistisches Reichsamt) and its research affiliate, Institut für Konjunkturforschung (IfK). ${ }^{\mathrm{I}}$ This business cycle research institute collected monthly and quarterly industrial statistics and produced an index of industrial production based on I928 weights. Wagenführ (I933) calculated a simplified version of this index back to I86I. A refined version of the same index was rebased to I936 after an industry census and later became the starting basis for the industrial production indices of both postwar Germanies.

The second source is provided by the estimates of Hoffmann (I965), who calculated various different estimates of German national accounts including an output account and an index of industrial production. Being part of the international comparative national accounts project under the guidance of Simon Kuznets, Hoffmann's data on German industrial output soon gained general recognition and are reproduced in all major international compilations of historical output series - most prominently, Mitchell (I975) and Maddison (I995). Figure I plots both estimates against one another.

Both series are calculated for changing territory, excluding, inter alia, the mining and industry districts of Upper Silesia after 1920, and the Saar district between I920 and 1935. Apparently there exists a level effect in I925 that drives a wedge between Hoffmann's data and the official series of industrial production. Also, growth in Hoffmann's series during the I930s is slightly higher. Tracing this displacement effect on a sector-by-sector basis, one of the most dynamic series is Hoffmann's estimate of value added in the metalprocessing industry. Hoffmann stipulates that output in this sector almost tripled between I9I3 and I938. As metal-processing accounts enter his index of industrial production with a weight of $\mathrm{I} 7$ per cent, this is evidently a major factor determining the dynamics of the aggregate as a whole.

To calculate the output of the metal-processing industry, Hoffmann chooses the rather indirect way of inferring output from employment and

\footnotetext{
I The Institute was established in 1927 in an effort to produce business cycle indicators and to build up monthly industrial statistics as in the United States, see Tooze (200I). It was separated from the Reichsamt in 1936 and renamed Deutsches Institut für Wirtschaftsforschung (DIW). Under this name it still exists today. See Krengel (I986) for a historical account by a member.
} 


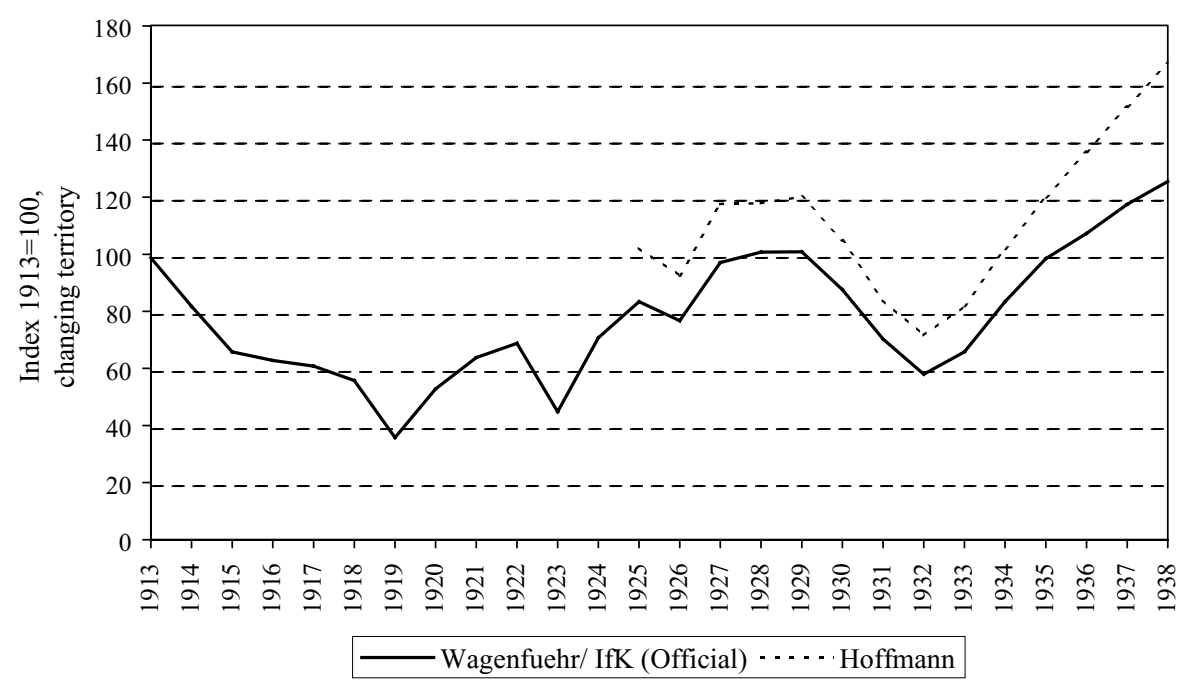

Figure I. Industrial production in Germany, 1913-1938.

Sources: Wagenfführ (1933), Hoffmann et al. (1965).

a self-constructed earnings series under the assumption of constant wage shares. This assumption looks fine when viewed from the perspective of Cobb-Douglas production functions or of steady-state growth with Harrodneutral progress. However, it is less innocuous under more general CES technologies and collective bargaining, and introduces potential bias.

This problem has plagued the German debates about wage shares and unit labour cost in the Weimar Republic. Borchardt (I99I [I979]) had employed a national income series (from Glismann et al. 1978) that was constructed independently of Hoffmann's output data and found strong evidence of rising unit labour cost. Holtfrerich (1984) recalculated labour unit cost data from Hoffmann's output series and found no increase over 1913. In a comparison of the different output and income estimates, Ritschl (I990) singled out Hoffmann's output data as the only estimate under which the labour share remains roughly constant relative to I9I3.

Why Hoffmann chooses to proceed in this way is not entirely clear, as there exists a wealth of time series on output in the various subsectors of metal processing in Germany. The official index of industrial production includes data on shipbuilding, automobile production, and machine building. Series on electrical industry and the - far smaller - optical industry are available from 1928 on an annual basis. ${ }^{2}$ Both series were completed for 1913 and I $925^{-27}$ by a group around Gehrig (I96I) at Munich's IFO institute.

${ }^{2}$ See, for example, Statistisches Handbuch von Deutschland (I949) as a standard reference. 
Table I. Inferring output from employment in metal-working industry (Balderston).

\begin{tabular}{|c|c|c|c|c|c|c|c|}
\hline & \multirow{2}{*}{\multicolumn{2}{|c|}{$\begin{array}{l}\text { Hoffmann } \\
\text { Employment in }\end{array}$}} & \multicolumn{3}{|c|}{ Reconstruction } & \multirow{3}{*}{ Output } & \multirow{2}{*}{ Hoffmann } \\
\hline & & & \multicolumn{2}{|c|}{ Employment } & \multirow[t]{2}{*}{ Wages } & & \\
\hline & $\begin{array}{l}\text { Metal } \\
\text { making }\end{array}$ & $\begin{array}{l}\text { Metal } \\
\text { processing }\end{array}$ & $\begin{array}{l}\text { Share of } \\
\text { metal } \\
\text { processing } \\
\text { in total }\end{array}$ & $\begin{array}{l}\text { Metal } \\
\text { processing }\end{array}$ & & & \\
\hline & (I) & $(2)$ & (3) & (4) & (5) & (6) & (7) \\
\hline I9I3 & 443 & $\mathrm{I}, 887$ & & & & & \\
\hline 1913 & 2,33 & & 0.8099 & $I, 887$ & 100 & IOO & IOO.O \\
\hline 1925 & 2,8 & & 0.8099 & 2,315 & 107.2 & I3I.5 & $I 3 I .4$ \\
\hline 1926 & 2,2 & & 0.8099 & I, 839 & I06.6 & 103.9 & 103.9 \\
\hline 1927 & 2,6 & & 0.8099 & 2,180 & $\mathrm{I} 23.5$ & I 42.7 & 142.6 \\
\hline 1928 & 2,8 & & 0.8099 & 2,277 & 126.5 & 152.7 & 163.5 \\
\hline 1929 & 2,6 & & 0.8099 & $2,17 \mathrm{I}$ & 138.2 & I 59.0 & 170.3 \\
\hline
\end{tabular}

Notes and Sources: Cols (I, 2) Hoffmann (1965, p. I96); cols (4-6) Balderston (I993, Table 3A); col. (7) Hoffmann (I965, p. 358).

Rather than employing this information, Hoffmann interpolates census data on employment in a very broad classification of metal processing, which also includes the electrical and optical industries. For the interwar years, the annual interpolating series is even aggregated over both metal making (mainly, iron and steel) and metal processing. Balderston (I993) has attempted to reconstruct Hoffmann's interpolation method. Table I reproduces Balderston's method in simplified fashion.

The first two columns in Table I show employment in metal making and metal processing. As no independent annual observations for metal processing are available, Hoffmann (1965, p. 198) uses the breakdown of I9I3 (8I per cent) and applies it to the subsequent years. To arrive at output, Hoffmann imputes an - again, rather indirect - estimate of product wages: see Balderston (1993). Multiplying this index of product wages in col. (5) by estimated employment in metal processing in col. (4) yields an estimate of real output in (6). As can be seen by comparison with Hoffmann's own output estimate (7), Balderston's reconstruction of the method works well to 1927 but not thereafter.

It is apparent that this estimation strategy critically depends on two things: first, on the validity of the employment figures themselves, and second, on output per person being strictly proportional to the real wage. The first assumption is evidently problematic enough. As to the second assumption, it is equivalent to stipulating that technology was Cobb-Douglas and that shifts in the distributional position of labour were absent. This assumption seems to be more of a problem than Hoffmann had anticipated. 
Table 2. Inferring output from employment in machine building (Balderston).

\begin{tabular}{|c|c|c|c|c|}
\hline & $\begin{array}{l}\text { Employment } \\
\text { ooos }\end{array}$ & $\begin{array}{l}\text { Output per worker } \\
\text { (tons) }\end{array}$ & $\begin{array}{l}\text { Total output } \\
\text { I9I3 = I00 }\end{array}$ & $\begin{array}{l}\text { Unit export value } \\
\text { I925 = IOO }\end{array}$ \\
\hline & (I) & (2) & (3) & (4) \\
\hline I913 & 1,220 & I.25 & IOO & \\
\hline 1925 & $\mathrm{I}, 572$ & 1.06 & 109.3 & 100 \\
\hline 1926 & 1,229 & & 94.8 & IOI. 8 \\
\hline I927 & $\mathrm{I}, 502$ & & I21.6 & 105.3 \\
\hline I928 & $\mathrm{I}, 676$ & & I38.9 & I08.8 \\
\hline 1929 & $\mathrm{I}, 520$ & & I 40.2 & II 2.6 \\
\hline
\end{tabular}

Notes and Sources: Balderston (1993, Table 4A).

\section{An alternative estimate: the IfK data}

To produce a better estimate, attention needs to be focused on the machine building and electrical industries only, as deviations between Hoffmann and Wagenfuehr for shipbuilding industry do not seem to matter very much. Balderston (1993) has extended Hoffmann's estimation procedure to machine building, attempting to infer output from employment in that sector. His method, shown in Table 2, is to multiply estimated employment (col. I) by an estimate of output per worker (col. 2). The output index he obtains in this way for the 1913-1925 period is then spliced to nominal value added from 1925, which he deflates by a self-constructed index of unit export values for machinery. As a result, machinery output in 1925 is estimated to have been about Io per cent higher than in 1913. Also, Balderston's data show machine building to have increased by 27 per cent from 1925 to 1928 .

These estimates do not square well with contemporary data on machinery output (Table 3). The German machinery producers' association, VDMA, produced figures on gross sales from questionnaires among its members, which later were also included in the official statistics (col. I). The VDMA also collected data on the tonnage of machinery produced, from which it produced an estimate of real output in 1925 at 1913 prices (col. 2). Later research by Gehrig (196I) combined these data and later VDMA reports into a time series (col. 3) of gross sales from 1925 to 1938, which exhibits slightly lower levels almost throughout. Deflation is by the official series of machinery prices (col. 4). Series (5-7) show three different estimates of machinery output at constant prices. For 1925, volumes range from 64 per cent to 75 per cent of the output level of I9I3. We adopt the original VDMA (col. 6) figure for 1925 as a compromise estimate and splice Gehrig's estimate of machinery output to its 1925 level. The resulting time series of machinery output (col. 8) is only slightly higher than Gehrig's deflated series in (col. 7). 
Table 3. Recalculating output in machine building.

\begin{tabular}{|c|c|c|c|c|c|c|c|c|c|}
\hline & Sales & & & Prices & Outpu & & & & \\
\hline & VDMA & & Gehrig & & VDM & & Gehrig & new & IfK \\
\hline & & $\mathrm{M} / \mathrm{RM}$ & & & & dex I9 & $3=100$ & & \\
\hline & current & constant & current & & & & & & \\
\hline & (I) & (2) & (3) & (4) & (5) & (6) & (7) & (8) & (9) \\
\hline I9I3 & 2,800 & 2,800 & 2,800 & IOO.0 & I00.0 & I00.0 & I00.0 & IOO.0 & 100.0 \\
\hline 1925 & 2,900 & I,933 & 2,509 & I38.0 & $75 . \mathrm{I}$ & 69.0 & 64.9 & 69.0 & 66.9 \\
\hline 1926 & 2,500 & & 2,159 & 139.7 & 63.9 & & 55.2 & 58.7 & $57 . I$ \\
\hline I927 & 3,400 & & 2,825 & I39.5 & 87.0 & & 72.3 & 76.9 & 75.0 \\
\hline I928 & 4,000 & & 3,728 & I 44.8 & 98.7 & & 91.9 & 97.8 & $94 . I$ \\
\hline 1929 & & & 3,883 & I 47.8 & & & 93.8 & 99.8 & $97 \cdot 5$ \\
\hline I930 & & & 3,042 & I 49.7 & & & 72.6 & 77.2 & 78.2 \\
\hline I93 I & & & 2,209 & I46.0 & & & 54.0 & 57.5 & 56.0 \\
\hline I932 & & & $I, 364$ & 132.9 & & & 36.7 & 39.0 & 38.3 \\
\hline I933 & & & $\mathrm{I}, 547$ & I 29.2 & & & 42.8 & $45 \cdot 5$ & $45 \cdot 7$ \\
\hline I934 & & & 2,053 & I 28.4 & & & $57 . \mathrm{I}$ & 60.7 & $6 I . I$ \\
\hline I935 & & & 2,697 & I 27.8 & & & 75.4 & 80.I & 80.2 \\
\hline I936 & & & 3,286 & I28. I & & & 91.6 & $97 \cdot 4$ & 96.4 \\
\hline I937 & & & 4,127 & I 28.2 & & & II 5.0 & 122.2 & 116.7 \\
\hline I938 & & & 4,932 & $\mathrm{I} 28.2$ & & & I37.4 & I46.I & 138.9 \\
\hline
\end{tabular}

Notes and Sources: Col. (I) VDMA (1930, pp. 57,59), Gross Output at Current Prices. Col.

(2) VDMA (1930, p. 57), Gross Output at I9I3 Prices. Col. (3) Gehrig(I96I, p. 38). Col. (4) Statistisches Jahrbuch für das Deutsche Reich, various issues, index of machinery prices.

From 1929 to 1938: Statistisches Handbuch von Deutschland, p. 460/Table 3. Col. (5) = $(\mathrm{I}) /(4)$, Index I9I3 = I00. Col. $(6)=(2) /(4)$, Index I9I3 $=$ I00. Col. $(7)=(3) /(4)$, Index I913 $=$ I00. Col. $(8)=(7)$, spliced to the level of (6) in I925. Col. (9) IfK (I935) and IfK Halbjahresberichte zur Wirtschaftslage, various issues, rebased from $1928=\mathrm{I} 00$.

The difference between our recalculation (col. 8) and Gehrig's series (col. 7) rests on how machinery sales for 1925 are deflated. Balderston (I993) appears to dismiss the official price index of machinery as too low, and constructs his own, higher deflator from export unit values. VDMA's deflated machinery output data for 1925, shown in cols 2 and 5, suggests a similar correction. Dividing deflated sales (in col. 2) into nominal sales (in col. I), we find the implicit price deflator for 1925 to be equal to I50.0 instead of I38. Splicing Gehrig's deflated series to this estimate implicitly adjusts the price index in col. 3 upwards by twelve index points. This is very much in line with the unit export values reported in Balderston (I993, p. II2). Still, there is little discrepancy between the result and Wagenführ's index of machinery production (col. 9), at least for the Weimar years. Our new index is constantly about three or four index points higher, but no more than that. Only in the mid-1930s does the revised estimate exhibit somewhat higher growth than the IfK estimate. This may be due to an underestimation of 
Table 4. Estimates of factory-floor employment in machine building and metal processing.

\begin{tabular}{|c|c|c|c|c|c|c|c|}
\hline & \multicolumn{3}{|c|}{ Machine building } & \multicolumn{4}{|c|}{ Metal processing } \\
\hline & \multicolumn{2}{|c|}{ VDMA estimates } & \multirow[t]{2}{*}{ Census data } & \multicolumn{2}{|c|}{$\begin{array}{l}\text { Factory inspector } \\
\text { reports }\end{array}$} & \multicolumn{2}{|c|}{ Balderston } \\
\hline & ooos & $\begin{array}{l}\text { Index } \\
\text { I9I3 = I00 }\end{array}$ & & ooos & $\begin{array}{l}\text { Index } \\
\text { I9I3 = IOO }\end{array}$ & ooos & $\begin{array}{l}\text { Index } \\
\text { I9I3 = IOO }\end{array}$ \\
\hline & (I) & (2) & (3) & (4) & (5) & (6) & (7) \\
\hline I913 & 460 & 100 & & $\mathrm{I}, \mathrm{I} 73.5$ & 100 & $\mathrm{I}, 220$ & 100 \\
\hline 1924 & 442 & $96 . \mathrm{I}$ & & I, 4 I I. 5 & $\mathrm{I} 20.3$ & & \\
\hline 1925 & 452 & 98.3 & $656.5^{*}$ & & & $\mathrm{I}, 572$ & I28.9 \\
\hline 1926 & 440 & $95 \cdot 7$ & & I,008.6 & 85.9 & I,229 & I00.7 \\
\hline I927 & 536 & II6.5 & & $\mathrm{I}, 263 . \mathrm{I}$ & I07.6 & $\mathrm{I}, 502$ & I23.I \\
\hline I928 & 549 & II 9.3 & 444.2 & I,3I6.I & II 2.2 & $\mathrm{I}, 576$ & $\mathrm{I} 29.2$ \\
\hline
\end{tabular}

Notes and Sources: Col. (I) VDMA [1927, p. 20; 1930, p. 13]. Col. (3) Wirtschaft und Statistik Sonderheft Io (193I), p. 83. * Includes unemployed, VDMA [1930, p. 52]. Col. (4) Statistisches Fahrbuch fuer das Deutsche Reich, various issues. Col. (6) Balderston [1993, Table 4A].

the actual price level in the official index of machinery prices (col. 4) after 1936. However, the results of Fremdling and Staeglin (2003) on the industry census of 1936 suggest that there might be an under-reporting problem in the official output data beginning in 1936 .

Regarding the comparison between 1925 and I913, Balderston (1993, pp. 448f) dismisses the VDMA figures as too low. However, he accepts the same figures for the years from $1925 \mathrm{on}$. What appears to speak in favour of Balderston's scepticism are the employment data - at least at first sight. If both his employment figures and the VDMA output data were true, he argues, per capita output in 1925 would have been only 64 per cent of its prewar level, which he dismisses as implausible. Due to changes in the industry classification system, reliable time series on employment in machine building are apparently not to be had. VDMA's own estimates of blue-collar workers employed are shown in Table 4, col. (I). These can be supplemented with employment figures (col. 3) from the 1928 census of machine building, which however appears to apply to a slightly different classification. Balderston therefore calculates his own employment data from the annual reports of factory inspectors. These data cover all establishments with io or more workers in machine building and its adjacent industries, including electrical and optical industry. The reporting base changed in 1926 to five or more workers, which induces Balderston (1993, p. 444) to upwardly adjust his employment data for the previous years. ${ }^{3}$ Balderston finds employment

${ }^{3}$ For a description of the adjustment, see Wirtschaft und Statistik (I927, n. I6, p. 695).

Balderston, p. 445, puts the new threshold at six, not five employees. 
in 1928 to have been almost 30 per cent higher than in 1913 (col. 7 in Table 4$) \cdot{ }^{4}$

Recalculating the data, we find the evidence on employment in that sector to be less impressive. The factory inspectors' reports switched from counting blue-collar workers to including all employees in 1926, without giving much notice of the change. In Table 4, col. (4) provides a consistent series on bluecollar employment only, which shows that employment in the total metal working industry in 1928 was a mere 12 per cent higher than in 1913. We neglect the widening of the reporting base in 1926, which would induce a further downward correction of the index (for example, to 108 rather than II 2 index points in 1928). The series also suggests that some time in 1925 and 1926, employment in that sector fell by almost a third.

Indeed, the stabilisation crisis of $1925 / 1926$ must have been a deep one, and was accompanied by structural changes in the labour market. Labour time reductions in the wake of the eight-hour day had been significant, amounting to about Io per cent (Balderston I993, p. 438; VDMA I927, p. 38). The poststabilisation slump in machine building was accompanied by a fall in orders of about 40 per cent, see VDMA (I926a, p. I7). VDMA estimates indicate that, beginning in 1925, almost 30 per cent of the blue-collar workers in the industry lost their jobs, while another 37 per cent were put on part time labour. As a result, over 50 per cent of the remaining workforce in early 1926 was on short time. VDMA also reported regularly on the degree of underutilisation of capacity. According to this measure, firms operated below 60 per cent of capacity in 1925 and at a low of 55 per cent of capacity in early 1926, before recovery set in.

There is also companion evidence of an initial upturn in 1924. The last year of hyperinflation had brought a severe setback to postwar reconstruction, as after the French occupation of the Ruhr, output of this industrial heartland of Germany had dropped dramatically. By the beginning of 1924, the political struggle about the resources of the Ruhr had ended and recovery was underway. After a short interruption due to monetary tightening in the second quarter of 1924, orders increased by over 60 per cent until early 1925, when the crisis set in. This fits well with the commonly accepted interpretation of German industry having come out of the hyperinflation with an overhang of labour. Real labour cost only came to be felt when monetary tightness and the high-tax system implemented in 1924 began to have their effects. VDMA's publications are full of complaints about tax burdens, interest rates, and the attempts by fiscal and monetary authorities to stem capital inflows into Germany. Later in 1926, the lobbying of German industry against these restrictions proved successful. Tax cuts were implemented and new spending programmes launched, and Schacht's attempts as president

\footnotetext{
${ }^{4}$ Recalculating the data for 1928 from the sources, I find total employment in ooos to be I,576, not I,676, and have inserted the corrected data in Table 4 .
} 
of the Reichsbank to halt the surge of foreign borrowing were thwarted (see Hertz-Eichenrode 1982 and Ritschl 2002).

A third and obvious way of checking the validity of the VDMA output data would be to examine investment activity in German industry during the inflation period. The course of investment during the hyperinflation has itself been the subject-matter of debate. Abelshauser (I978) argued that there must have been an investment boom during the inflation years, especially during I $92 \mathrm{I} / 22$. However, the point about an investment boom would not be easy to make. As Figure I above shows, industrial output in Germany in the wake of World War I was dismally low. Starting out from less than 40 per cent of the prewar level in 1919, it recovered to 70 per cent in 1922. No doubt this was a boom of sorts in growth rates, but levels of output remained critically low. Gehrig (I96I) has produced an estimate of the German capital stock for the war and postwar period, which again shows very low levels of real capital formation in the first five postwar years. As shown by Spoerer (1997, p. 284), investment during the inflation period remained low also in relative terms: the investment-output ratio calculated from these data was markedly lower than in any year between 1925 and 1929.

This evidence is also corroborated by a microstudy of major German machine building companies. Lindenlaub (1985) has shown that during the inflation years, capacity increased mainly through additional labour, whereas investment remained about 30-50 per cent below prewar levels. This, he argues, was less than depreciation, with the effect that after the stabilisation of 1924, the capital stock was technically obsolete. By implication, the ratio of capital to labour in efficiency units seems to have declined, as did the investment-output ratio. Of course the sample drawn by Lindenlaub is far too small to be representative. However, it covers some of the leading German machinery producers, including Krupp (known to the world for its steel division but also for its war production), Deutz (which had commissioned the development of the first Otto gasoline engine), MAN (which had commissioned the development of the first Diesel engine), and Maschinenfabrik Esslingen, a major locomotive builder. These companies were all either in the railway business or supplied marine engines. As both the railways' rolling stocks and the German merchant fleet had been sharply reduced as part of Germany's reparations and therefore needed to be restocked, each of these firms must have fared better than the rest of the industry. Hence it seems safe to conclude that investment in these companies was slightly higher than the industry average. Still, even for these industry leaders, the overall investment record for the inflation period is poor.

A further, though necessarily crude, way to infer machine building activity indirectly is by measuring output and consumption of iron and steel. This indicator had figured prominently in German business-cycle research where it was employed as a short-term business cycle predictor - a classical piece on 

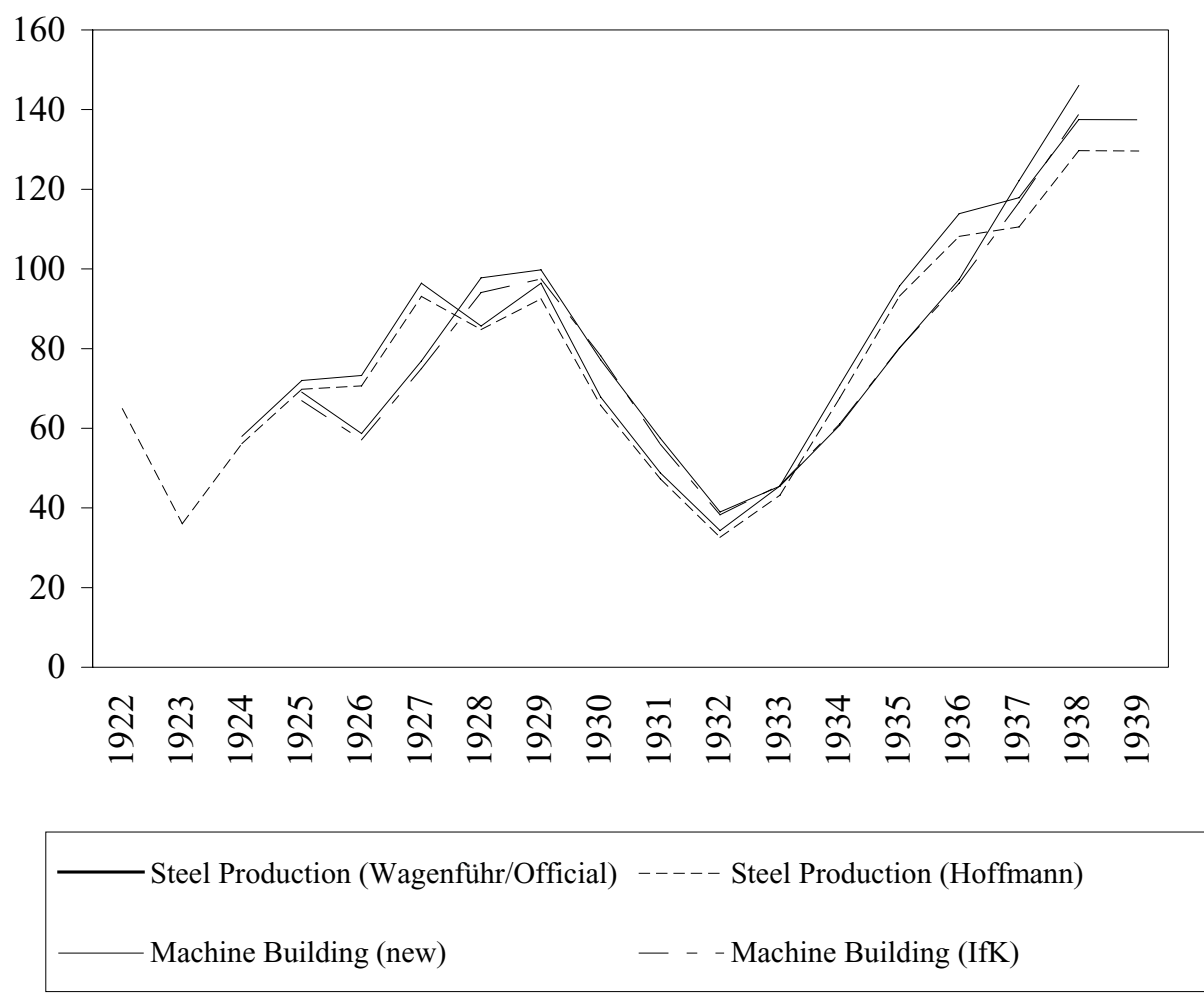

Figure 2. Steel output in Germany vs machine production, $(1913=100)$. Sources: Germany: Wagenführ (1933). Britain: Mitchell (1990), output of steel ingots.

this is Spiethoff (1924). It was used again by Gehrig (196I) to proxy output of machine-building during the inflation years.

Plotting our estimates of machine building activity from Table 3 together with indices of steel output, we find an obvious co-movement: there is precious little room for any under-reporting in the machinery data; all series move closely together and exhibit the same levels relative to I9I3 (Figure 2).

Looking for a possible explanation of Germany's low iron and steel output relative to 1913, the main factor was territorial losses. In I920, Lorraine was returned to France, parts of Silesia went to Poland, and the Saar district was put under international control (up to 1935). All three provinces had large heavy-industry capacities, and together accounted for 35 per cent of Germany's steel output of I913 (Wagenführ I933). Figure 3 plots steel output in Germany's reduced I92 I territory against an index of British steel production, with a striking result: once the territorial correction is applied to the data, the German steel industry experienced pretty much the same development as its British counterpart. 


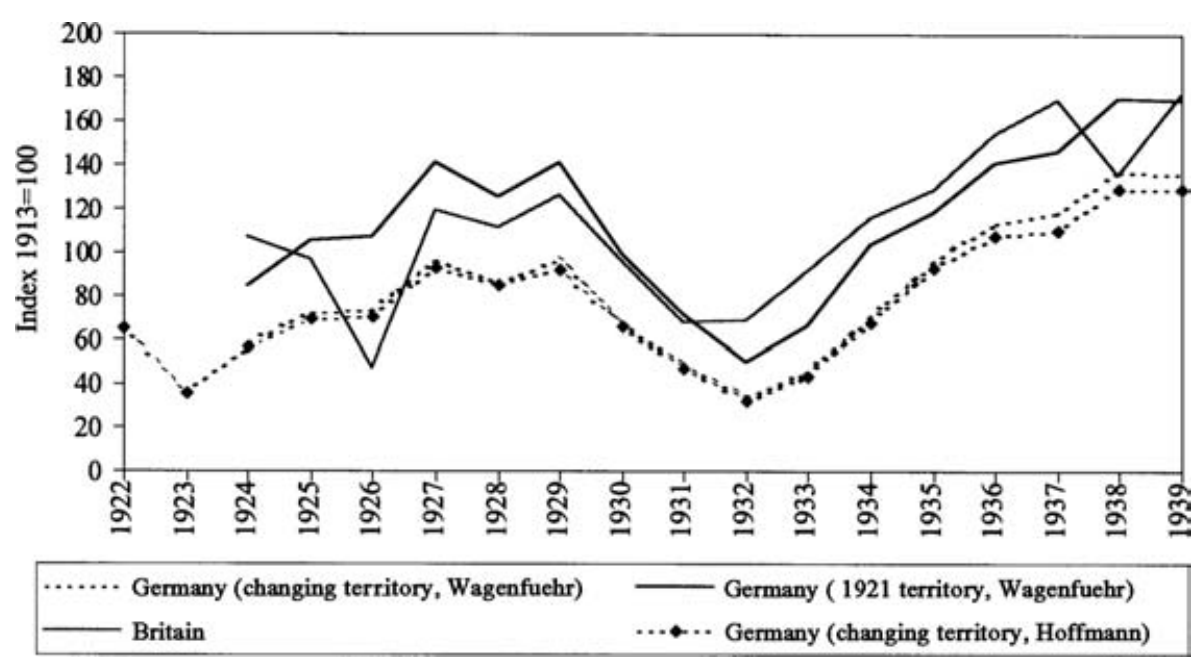

Figure 3. Steel output in Germany and Britain on constant and changing territories.

Sources: Germany: Wagenführ (I933). Britain: Mitchell (I990), output of steel ingots.

By 1922, German iron and steel output had almost recovered to its prewar level when measured on postwar territory. Output dropped by almost 50 per cent in 1923, which is mostly due to passive resistance against the French occupation of the Ruhr. The subsequent recovery was interrupted again in 1926. Domestic consumption of iron and steel was about 25 per cent lower than before the war, which comes very close to the reduction in machinery output of 22 per cent. Relative to Britain, the capacity losses were never compensated before the war: even in 1939, Germany's steel output relative to I9I3 was almost exactly the same as Britain's; no catching-up to compensate for the territorial losses of I92 I had taken place. Cutting through the backward and forward linkages of German heavy industry had been a side-effect of the territorial changes of I92I, and was clearly successful from the viewpoint of weakening Germany's heavy industry base. Given that the industrial regions ceded in I92 I disappeared behind high tariff walls, the subsequent slump in German machine building cannot come as a surprise. Germany had lost its tariff sovereignty in the Treaty of Versailles and regained it only in 1925 . During $1924 / 25$, customs treaties were concluded with most signatory powers of the Treaty, and led to widespread reductions of tariffs and trade barriers that had impeded German machinery exports. By 1926, Germany was about to resolve its tariff conflict with France, but was still involved in a tariff war with Poland up to $1925 / 6$. VDMA (1926b, p. 46f) provides a detailed survey of the customs treaties concluded in that year. After 1926, exports of German machinery indeed recovered quickly. Given the severe restrictions on German capital goods exports in the preceding 
years, the subsequent rapid recovery of German exports documented by Balderston (I993, p. 87) is not surprising. Still, Germany's overall export performance in 1929 compared to 1913 is below the European average, and also lower than that of Britain. Again, there seems little reason to doubt the veracity of the machine output data.

The VDMA data are also consistent with the official statistics on aggregate investment since I924. Based on the work of Keiser and Benning (I93I), Germany's Statistical Bureau published aggregate investment data inferring investment from the analysis of company balance sheets, annual reports, and estimates of business associations and cartels. Gehrig (I96I) employed a perpetual inventory approach to measuring aggregate investment during the interwar years. His results build on the output of investment goods shown in Table 3. As these confirm the official investment data very well, both estimates support one another.

Drawing the arguments of this section together, there seems to be good reason to trust the official figures on machinery output, which fit other available data as well as complementary evidence on the intensity of the 1925 business slump. Put differently, there is little evidence to support Hoffmann's estimates, according to which activity in that sector would have had to have been almost 50 per cent higher than it plausibly was.

\section{Industrial production without spurious growth: the adjusted data}

Among the other main sectors of metal processing, the various available series on shipbuilding and on the output of motor vehicles largely follow similar patterns. In the following, we employ Hoffmann's series, which he discards in favour of his problematic wages-cum-employment estimate. The only remaining task is to find a suitable series for the electrical industry. Gehrig (I96I) has derived such a series from official data. ${ }^{5}$ Table 5 summarises the results, constructing a new index of production for metalprocessing industry.

The starting point of Table 5 (col. I) is again the estimate of machinery output from Table 3 (col. 8). Electrical industry (col. 4), whose value added data are taken from Gehrig (I96I), was more dynamic than machine building. We deflate the value added data by the price index for machinery (col. 3), which also includes electrical motors. No separate price index for electrical products seems available. The combined production index for machinery and electrical industry in col. (5) is weighted by the value added of

\footnotetext{
${ }^{5}$ Being interested in the production of capital goods in the German economy, Gehrig (I96I) provides data on the portion of output that goes into investment. The data shown in Table 6 above are reconverted to the full output of the respective industries using the proportions provided by Gehrig.
} 
Table 5. Recalculating output in German metal-processing industry.

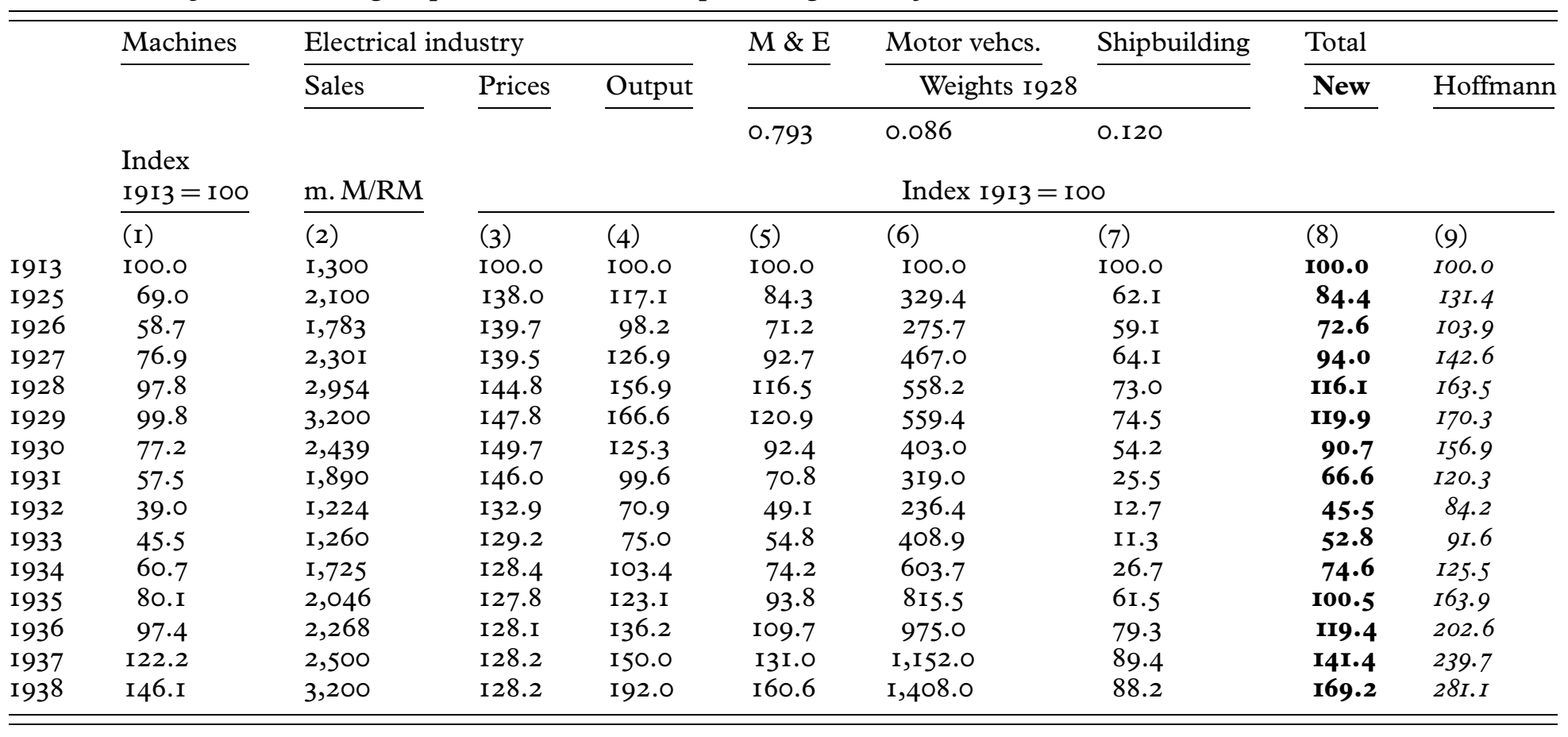

Notes and Sources: Col. (I) Real output in machine building, see Table 3(8). Col. (2) Gross sales of electrical and optical industry at current prices, Gehrig (196I, pp. 38, 4I). Col. (3) Index of machinery prices, Statistisches Fahrbuch für das Deutsche Reich, various issues, I929 to I938: Statistisches Handbuch von Deutschland, p. 460/Table 3. Col. (4) Real output in electrical industry, $(4)=(2) /(3)$, index I9I3 = Ioo. Col. (5) Combined real output in machine building and electrical industry, weighted by gross output in I9I3. Col. (6) Output of motor vehicles, Hoffmann (I965, p. 358). Col. (7) Shipbuilding production, Hoffmann (1965, p. 358). Col. (8) Total output of metal processing industry; cols (8) =(5), (6) and (7), Index 1928, rebased to Index 1913 = I00. Index weights for Col. (8) from IfK (1935, p. 99), adjusted for electrical industry. Col. (9) Hoffmann index of metal-working output, Hoffmann (1965, p. 358). 
each industry in I9I3. To construct the index for metal-processing industry (col. 8), index weights need to be found that combine the series in (5) with motor vehicle production (6) and shipbuilding (7). As Hoffmann provides no index weights, those from the index of industrial production of Wagenführ (I933) are used instead, where proper allowance is made for the electrical industry.

The revised index is on average 45 index points lower than Hoffmann's index (reported in Table 5 as col. 9) during the I920s. The difference jumps to an average difference of 67 index points in the I930s. Output at the troughs of the recessions of $\mathrm{I} 926$ and $\mathrm{I} 932$ is at 72.6 and 45.5 per cent of the I9I3 benchmark respectively. Hoffmann's index would show IO4 and 84 index points for the same years. At the peak of 1929 and in the prewar year of 1938 , the revised index attains I 19.9 and I69 index points. In contrast, Hoffmann's index would instead rise to $\mathrm{I} 7 \mathrm{O}$ and $28 \mathrm{I}$ index points respectively. This is not easy to reconcile with the available evidence.

As a next step, we will insert the revised output index of metal-processing industry into Hoffmann's industry aggregate. The aim of this exercise is to provide upper and lower bounds for a future consensus estimate of industrial production. Upon inspection of the various entries, Hoffmann's industrial production index leans towards modern, fast-growing industries, whereas the IfK index of production seems more centred on traditional, slow-growing industries. Hence we should expect that, once the bias in the metal processing series has been taken out, Hoffmann's revised series can serve as a plausible upper bound, while the IfK index may be a plausible lower bound.

The Hoffmann (I965, p. 390-4) index of industrial production is a chain index based on census employment weights, all multiplied by the value added of that respective industry in 1936. In the relevant time bracket, it employs the census weights of 1907 and 1933, spliced to each other in I925. For that year, there exists an employment census whose results Hoffmann does not use. This 1925 census also provides revised results for the 1907 census, calculated for Germany's smaller I92 I territory. ${ }^{6}$ Above, we suggested that the territorial changes after World War I significantly affected Germany's industry structure. Therefore, use of these revised weights is clearly preferable.

In contrast, the IfK index of industrial production for the interwar years is only available on a 1928 basis. As there is no hope of finding the true value added data of all industries for all years, comparison between the IfK index and the Hoffmann index introduces inevitable index number problems. To ensure proper comparison, Table 6 provides a whole array of recalculations of Hoffmann's index at various different base years. These include my reconstruction of Hoffmann's original series at original index weights

\footnotetext{
${ }^{6}$ See Statistisches Reichsamt (I927, p. I62f).
} 
Table 6. Recalculating the index of industrial production.

\begin{tabular}{|c|c|c|c|c|c|c|c|c|c|c|c|}
\hline & \multicolumn{5}{|c|}{ Chain index with weights $1907 / 1933$} & \multicolumn{2}{|c|}{ Index weights I933 } & \multicolumn{2}{|c|}{ Index weights I925 } & \multirow{3}{*}{\multicolumn{2}{|c|}{$\begin{array}{l}\text { I907/I925 I928 } \\
\text { Compromise } \\
\text { estimate }\end{array}$}} \\
\hline & I907 weiq & ghts uncorrected & & I907 weigh & ats corrected & & & & & & \\
\hline & \multicolumn{2}{|c|}{ Hoffmann } & \multirow[b]{2}{*}{ Revised } & \multirow[b]{2}{*}{ Hoffmann } & \multirow[b]{2}{*}{$\begin{array}{l}\text { Revised } \\
\text { Upper bound }\end{array}$} & \multirow[b]{2}{*}{ Hoffmann } & \multirow[b]{2}{*}{ Revised } & \multirow[b]{2}{*}{ Hoffmann } & \multirow[b]{2}{*}{$\begin{array}{r}\text { Revised } \\
\text { Lo }\end{array}$} & & \\
\hline & Original & Reconstructed & & & & & & & & $\begin{array}{l}\text { Revised } \\
\text { pwer bound }\end{array}$ & $\begin{array}{l}\text { Official } \\
\text { d }\end{array}$ \\
\hline & (I) & (Ia) & (2) & (3) & (4) & (5) & (6) & (7) & (8) & (9) & (IO) \\
\hline I913 & IOO & 100 & IOO & IOO & $\mathbf{1 0 0}$ & IOO & IOO & IOO & 100 & $\mathbf{1 0 0}$ & IOO \\
\hline 1925 & IO3 & I03.8 & 93.9 & 100.2 & 90.6 & 93.8 & $87 . \mathrm{I}$ & 96.0 & 87.5 & 89.0 & 83.6 \\
\hline 1926 & 94 & $94 . \mathrm{I}$ & 86.3 & 90.9 & 81.9 & $85 . \mathrm{I}$ & 80.0 & 85.2 & 79.2 & 80.5 & 80.6 \\
\hline 1927 & II9 & II9.8 & I08.8 & I 5.7 & 105.6 & 108.3 & IOI.O & II I. 2 & 102.0 & 103.8 & IO3.o \\
\hline I928 & II9 & I20.5 & III.7 & II 6.3 & $107 \cdot 5$ & I08.9 & I03.7 & IIO.9 & 103.9 & $105 \cdot 7$ & IO2.O \\
\hline 1929 & I 2 I & I2I.6 & I 12.7 & II 7.4 & 106.5 & 109.9 & I04.6 & IIO.0 & 102.9 & $104 \cdot 7$ & 102.9 \\
\hline 1930 & I06 & I06.4 & $94 \cdot 3$ & I02.7 & 88.7 & 96.2 & 87.4 & 96.7 & 85.7 & 87.2 & 90.8 \\
\hline I93I & 85 & $85 \cdot 3$ & 74.9 & 82.4 & 70.4 & 77.1 & 69.5 & 77.4 & 68.0 & 69.2 & $74 \cdot 5$ \\
\hline I932 & 73 & 74.2 & 65.0 & 71.6 & 61.6 & 67.1 & 60.3 & 67.6 & 59.5 & 60.6 & 59.9 \\
\hline I933 & 83 & 84.2 & 74.6 & $8 \mathrm{I} \cdot 3$ & 71.5 & $76 . \mathrm{I}$ & 69.2 & $77 \cdot 4$ & 69.1 & 70.3 & 66.8 \\
\hline I934 & IO3 & IO4.I & 92.7 & 100.5 & 88.0 & $94 . \mathrm{I}$ & 86.0 & 94.9 & 85.0 & 86.5 & 85.0 \\
\hline 1935 & I 2 I & I 21.8 & 109.3 & II 7.6 & 102.9 & IIO.I & IOI.4 & IIO.2 & 99.4 & IOI.I & 97.7 \\
\hline I936 & I37 & I 37.4 & 122.3 & I32.7 & 114.2 & $\mathrm{I} 24.2$ & II 3.4 & 123.8 & $I I O .3$ & 112.2 & 108.8 \\
\hline I937 & I53 & I 53.2 & 136.4 & I 47.9 & 127.0 & I38.5 & I26.5 & 137.9 & $I 22.7$ & 124.8 & II9.0 \\
\hline I938 & I68 & I68.6 & 150.9 & I62.8 & 140.4 & I 52.4 & 140.0 & I5I.8 & 135.6 & 138.0 & 127.0 \\
\hline
\end{tabular}

Notes and Sources: See text. 
(col. 2), a proposed provisional consensus estimate (col. 9) and the original IfK index (col. IO).

Table 6 reports four different weighting schemes for Hoffmann's industrial production index, along with four versions of my revision. Given any weighting scheme, the difference between Hoffmann's series and my revision is up to ten index points in the I920s, which rises to $I 7$ index points in the late I930s. At Hoffmann's uncorrected index weights, the revised index (col. 2) peaks at II2.7 index points in I929, as opposed to I2I in the original series (col. I). For I938, the index is now at I5I instead of I68 points. Taking the I907 weights for postwar territory into account, the original series (col. 3 ) is about four to five index points lower than the original (col. I). The revised series (col. 4) now peaks in 1928 instead of in 1929 and is flatter in the I930s: relative to the pre-depression peak, the original series shows output increasing to 1938 by almost 40 per cent. Now, the cumulative increase is hardly more than 30 per cent. I regard the revised series (col. 4) as a plausible upper bound for industrial activity in interwar Germany relative to I9I3.

Two more revisions in Table 6 recalculate both Hoffmann's index and the revision in terms of 1933 and 1925 census employment weights, respectively. For the I920s, results for the revision, shown in cols. (6) and (8), are almost undistinguishable from the original IfK index in col. (IO). Only from I935/6 on does the revised Hoffmann series grows faster than the official one, without however ever attaining anything close to the original levels. I therefore regard the IfK series as a plausible lower bound of German industrial output.

As the data in Table 6 show, two thirds of the discrepancy between Hoffmann's series of industrial production and the official figures are probably spurious. About half the difference vanishes by replacing Hoffmann's metal processing series with the revised series from Table 5. To this extent, spurious output growth in Hoffmann's index emerges from the assumption of constant factor shares in metal processing. The remaining difference results from adjusting the index weights for I907 to Germany's post-I92 I territory. Once this is done, a plausible upper bound emerges; the discrepancy between it (col. 4) and the IfK series (col. IO) is about 5 index points in 1928 and $\mathrm{I} 3$ index points in 1938.

Rebasing the index to 1933 (col. 6) or 1925 (col. 8) almost entirely squeezes out the remaining difference with the IfK series (col. Io) for the I920s. This remarkable fact shows that Hoffmann's and Wagenfuehr's indices essentially paint the same aggregate picture, provided the proper corrections are made and the indices are expressed on the same basis. Moreover, it emerges that the discrepancies with the upper bound estimate (col. 4) depend entirely on whether the I925 index value is evaluated at I907 weights, as in (4), or at I925 weights, as in (8).

This gives rise to a further possible adjustment. Viewed from I925 at I907 weights, the I9I3 index at 1907 weights in col. (4) is obviously a Laspeyres 
index. Viewed from 1913 at 1907 weights, however, the 1925 index at 1925 weights in col. (8) would be a Paasche index. Hence, the Fisher index, which is the square root of their product, is a good compromise. The result of a Fisher index for 1925 is given in col. (9). It is obtained by taking the square root of the product of the 1925 index values in cols (4) and (8). The rest of the time series in this column is then a Laspeyres index on the $1907 / 1925$ basis found by the Fisher index for 1913 and 1925. For the 1920s, this appears to be the best estimate; I suggest it as a candidate for a future compromise index.

For the I930s, the discrepancy between the revised Hoffmann series and the official index is growing. This seems to be due to textiles and chemical products. Here, Hoffmann's index is heavily based on synthetic fibres and organic chemistry, whose output was booming under the import-substitution and autarky policies of Nazi Germany, whereas the official index seems to be rather on the conservative side, given its concentration on non-organic chemistry and on wool and cotton processing. The truth may therefore be somewhere in between; however this question is an open one and must be left for future research.

\section{National output without spurious growth: the aggregate evidence}

The implications of correcting the index of industrial production can be carried further. This section will insert the revised industrial output series from Table 6 above into Hoffmann's aggregate output account. Previous research by Ritschl (1990) and Spoerer (1997 and I998) has highlighted the discrepancies between Hoffmann's output and expenditure account on the one hand and the official tax-based income estimate on the other. Ritschl and Spoerer (1997) and Ritschl (2002) provided a detailed reconstruction of the expenditure account, and showed it is consistent with the official income series. Working with a provisional dataset, Ritschl (I998) examined the discrepancies between Hoffmann's expenditure account and the official income series. These differences largely disappear once the former is corrected by archival data not accessible to Hoffmann's project group at the time.

The following paragraphs do the same for the product account. I will retain most of Hoffmann's original estimate, and correct only for the industry entry. This exercise is necessarily provisional, as other entries in Hoffmann's estimates of value added would also have to be double-checked. Evidence on mining, agriculture, and construction in Ritschl (2004) suggests that adjustments are necessary in these sectors as well. Still, the effect of replacing the industry estimate in Hoffmann's product account with a revised version is large, as shown in Table 7.

Table 7 shows the product account data from Hoffmann (1965) in col. (I) along with a revised estimate (col. 3) and a deflated income account 
Table 7. A provisional revision of net national output, I9I3 and I925-38.

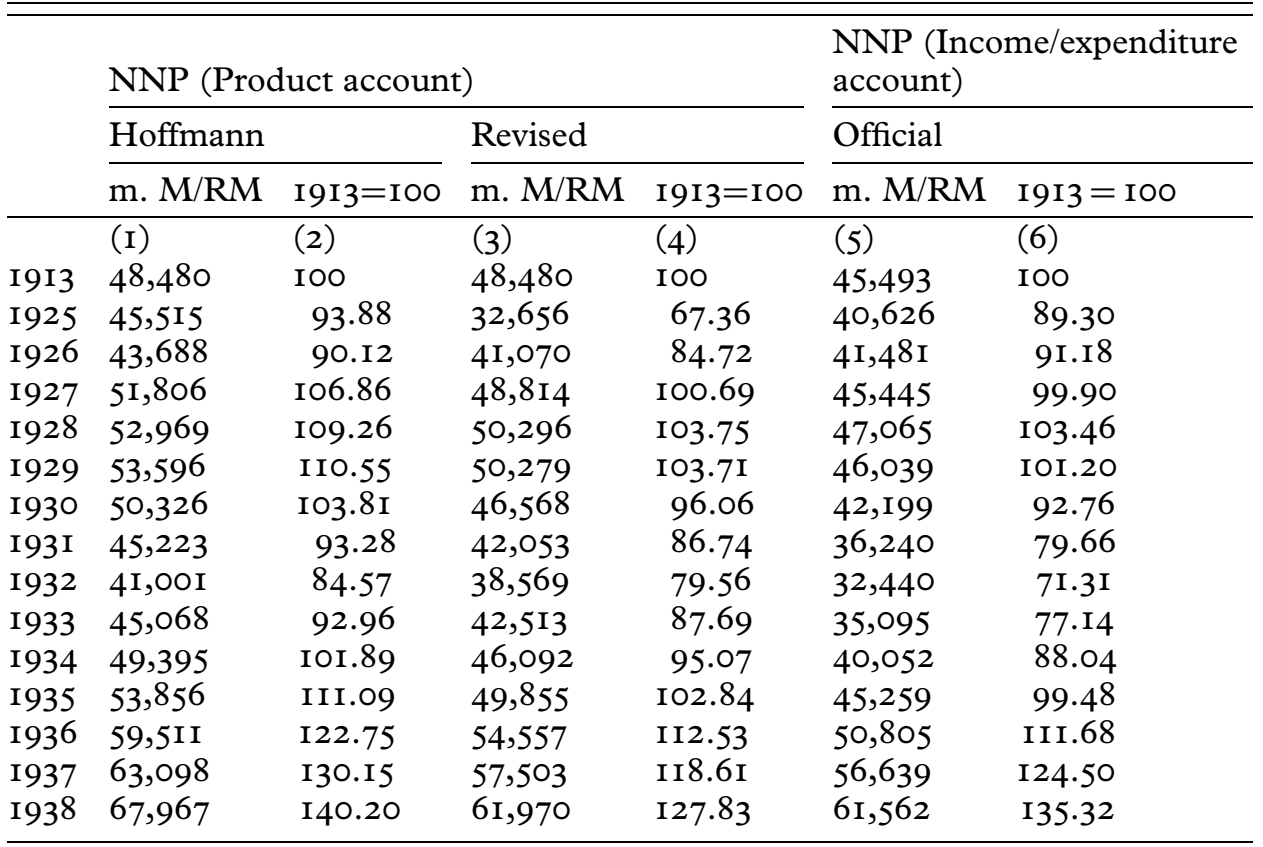

Notes and Sources: Col. (I) Hoffmann (1965, p. 455). Col. (3) Corrected by Table 6, (col. 9), using Hoffmann estimate for value added in I9I3 (I9902 mill M.). Col. (5) Ritschl (2002), Appendix, Series B.I.8. Implicit deflator for national product ibid., B.5.I/B.9.I.

(col. 5). The revision in (3) consists in replacing the manufacturing series in Hoffmann with the revision from Table 6 (col. 9) above. The income account (5) comes from a slight revision of the official data, and of earlier work by Hoffmann and Müller (1959) in Ritschl (2002, Table B. I). I deflate this series with the implicit deflator of national product that comes from comparing the nominal GNP series in Ritschl (2002, Table B.5) with the estimate of aggregate expenditure at I9I3 prices, ibid. Table B.9. Very similar GNP/NNP series and essentially the same deflator appear in Ritschl and Spoerer (I997).

Results in Table 7 can be read in two ways. One is to compare the levels of cols (3) and (5) in I9I3 currency. The starting level of the output estimate in I9I3 is over 6 per cent higher than that of the income estimate. Roughly the same holds for 1928 and I936. Evidently, there is a remaining level problem that is not resolved yet. This appears to confirm a conjecture of Fremdling (1988, I995).

A second way to read the evidence in Table 7 is in index number comparisons. Evidently, the revised product account in (4) is very much in line with the expenditure/income account in (6). This appears to solve the Hoffmann puzzle: once we dispense with his assumption of constant factor 
shares in metal-processing industry and insert the available industry data, the big differences between his national product data and the official accounts essentially disappear. Evidently, the fit is not perfect: the slump of 1926 is much deeper in the revised product account than in the income series, while the Great Depression is somewhat less pronounced. But output growth from I9I3 to 1938 as a whole is even slightly lower than the income account would predict. Apparently, there is no spurious growth in Hoffmann's output data once the necessary corrections are made.

\section{Conclusions}

Revisiting Germany's output data from the interwar period suggests that large parts of its output growth are spurious. The hitherto widely accepted data of Hoffmann (1965) show output in metal processing industry, a key sector of the German economy, to have grown almost threefold between I913 and 1938. This article has examined a wide array of evidence on the subsectors of that industry. I find that its output grew by slightly more than half that magnitude. Hoffmann worked from employment and wages to provide an input estimate, and assumed constant factor shares. This article has worked from output and value added data, which were readily available but which Hoffmann did not use. My own findings are in line with the indices produced by Berlin's Institut fuer Konjunkturforschung at the time.

The results for metal industry have their impact on the index of industrial production as a whole. Adjusting for the bias in metal working industry, industrial output in Germany increased markedly slower than Hoffmann's original data would predict. Presenting various different estimates with different index weights, we have provided what we believe are plausible upper and lower bounds for industrial output in interwar Germany. Evaluated at the same index basis as the official data, the revised Hoffmann index is almost indistinguishable from the IfK index. This confirms earlier research that has argued for sluggish recovery from World War I and a noticeable increase of the labour share in national income. Not just the Weimar business cycle but also the I930s come out as less dynamic than hitherto accepted. The lower and upper bounds provided in this article suggest that between 1913 and 1938, Germany's industrial production grew by 30 to 40 per cent, markedly less than the almost 70 per cent which Hoffmann obtained.

The results carry over to aggregate output. Measured on the basis of net national product (NNP), the trend differences between Hoffmann's product account and the official income account disappear once the revised manufacturing series is applied. The revised product account even comes out as slightly less dynamic than the income account. Evidently, the faster growth in Hoffmann's output data in both manufacturing and the aggregate economy is spurious. 
The results in this article are still tentative. Future research should build on the revised census data for 1936 being prepared in ongoing research by Fremdling and Staeglin (2003). From this adjusted benchmark, a new index of industrial production for Germany can be constructed. On this basis, both international comparisons - as in Broadberry (1997) and Broadberry and Fremdling (1990) - and intertemporal comparisons - as in recent work by Burhop and Wolff (2002) for the aggregate economy - will become possible, and will be free of spurious growth.

\section{Acknowledgements}

I am grateful to Ronald Albers, Michael Bordo, Stephen Broadberry, the late Trevor Dick, Angus Maddison, Mark Spoerer and Adam Tooze for helpful comments on earlier versions of this article. Financial support through the Spanish Ministry of Education's DGICYT programme (Project PB94-IIOI) is gratefully acknowledged.

\section{References}

ABELSHAUSER, W. (1978). Inflation und Stabilisierung. In Otto Büsch and Gerald Feldman (eds.), Historische Prozesse der deutschen Inflation 19I4-1924. Berlin: de Gruyter.

Balderston, T. (1993). The Origins and Course of the German Economic Crisis, 1924-I933. Berlin: Haude \& Spener.

Beaudry, P. and Portier, F. (2002). The French depression in the I930s. Review of Economic Dynamics 5, pp. 73-99.

Bentolila, S. and SAINT-PAUl, G. (2003). Explaining movements in the labor share. Contributions to Macroeconomics 3, Article 9.

BORCHARDT, K. (I979/199I). Constraints and room for manouvre in the economic policies of the early I930s. In K. Borchardt (eds.), Perspectives on Modern German Economic History and Policy. Cambridge: Cambridge University Press.

BROADBERRY, S. (1997). Anglo-German productivity differences, 1870-1990: a sectoral analysis. European Review of Economic History I, pp. 247-67.

BROADBERRY, S. and FREMDLING, R. (I990). Comparative productivity in British and German industry 1907-1937. Oxford Bulletin of Economics and Statistics 52, pp. 403-2I.

BROADBERRY, S. and RITSCHL, A. (1995). Real wages, productivity, and unemployment in Britain and Germany during the 1920s. Explorations in Economic History 32, pp. 327-49.

BURHOP, C. and WOLFF, G. (2002). A compromise estimate of the net national product and the business cycle in Germany, I85I-1913. Working Paper, University of Münster.

Cole, H. and Ohanian, L. (1999). The Great Depression in the United States from a neoclassical perspective. Federal Reserve Bank of Minneapolis Quarterly Review 23, pp. 2-24.

Cole, H. and OHANian, L. (2002). The Great UK Depression: a puzzle and possible resolution, Review of Economic Dynamics 5, pp. 19-44. 
Dimsdale, N. Horsewood, N. and van RiEl, A. (2004). Unemployment in Weimar Germany. Mimeo, Oxford University.

FISHER, J. and HORNSTEIN, A. (200I). The role of real wages, productivity and fiscal policy in Germany's Great Depression, I928-1937. Working paper 200I-7, Federal Reserve Bank of Chicago.

FREMDLING, R. (I988). German national accounts for the I9th and early 20 th century: a critical assessment. Vierteljahrschrift für Sozial- und Wirtschaftsgeschichte 75, pp. 33-57.

FREMDLING, R. (1995). German national accounts for the I9th and early 20 th Century. Scandinavian Economic History Review 43, pp. 77-100.

FREMDLING, R. and STAEGLIN, R. (2003). Die Industrieerhebung von I936: Ein Input-Output-Ansatz zur Rekonstruktion der volkswirtschaftlichen Gesamtrechnung für Deutschland im I9. und 20. Jahrhundert - ein Arbeitsbericht. Vierteljahrschrift für Sozial- und Wirtschaftsgeschichte 90, pp. 4I6-28.

GEHRIG, G. (I96I). Eine Zeitreihe für den Sachkapitalbestand und die Investitionen. Ifo-Studien 7, pp. 7-6o.

GlismanN, H. et al. (1978). Zur Natur der Wachstumsschwäche in der Bundesrepublik Deutschland. Eine empirische Analyse langer Zyklen wirtschaftlicher Entwicklung. Kieler Diskussionsbeiträge, n. 55.

HERTZ-EICHENRODE, D.(1982). Wirtschaftskrise und Arbeitsbeschaffung. Konjunkturpolitik 1925/26 und die Grundlagen der Krisenpolitik Brünings. Frankfurt am Main: Campus.

HofFMAnN, W. G. et al. (I965). Das Wachstum der deutschen Wirtschaft seit der Mitte des I9. Fahrhunderts. Berlin: Springer.

HofFmanN, W. G. and MÜLlER, J.-H. (1959). Das deutsche Volkseinkommen I85I-I957. Tübingen: Mohr.

HOLTFRERICH, C.-L. (I984). Zu hohe Löhne in der Weimarer Republik? Bemerkungen zur Borchardt-These. Geschichte und Gesellschaft Io, pp. I22-4I.

KEISER, G. and BENNING, B.(I93I). Kapitalbildung und Investitionen in der deutschen Volkswirtschaft 1924 bis 1928. Vierteljahreshefte zur Konjunkturforschung, Sonderheft, 22.

KRENGEL, R. (1986). Das Deutsche Institut für Wirtschaftsforschung (Institut für Konjunk Turforschung) 1925-1929. Berlin: Duncker \& Humblot.

LINDENLAUB, D. (1985). Maschinenbauunternehmen in der deutschen Inflation I9I9-I923. Berlin: Gruyter.

MADDISON, A. (I995). Monitoring the World Economy, I820-I990. Paris: OECD.

Mitchell, B. (I975). European Historical Statistics, Cambridge: Cambridge University Press.

Mitchell, B. (1990). British Historical Statistics. Cambridge: Cambridge University Press.

RITSCHL, A. (1990). Zu hohe Löhne in der Weimarer Republik? Eine Auseinanderset zung mit Holtfrerichs Berechnungen zur Lohnposition der Arbeiterschaft 1925-1932. Geschichte und Gesellschaft 16, pp. 375-402.

RiTSCHL, A. (I998). Measuring national product in Germany, I925-38: the state of the debate and some new results. In T. Dick (ed.), Business Cycles since 1820. Cheltenham: Elgar. 
RitsCHL, A. (2002). Deutschlands Krise und Konjunktur, I924-I934.

Binnenkonjunktur, Auslandsverschuldung und Reparationsproblem zwischen Dawes-Plan und Transfersperre. Berlin: Akademie Verlag.

RITSCHL, A. (2004). How and when did Germany catch up to Britain and the US? Results from a revised estimate, I88I-I950. Mimeo, Humboldt University.

RitsChl, A. and SPOERER, M. (I997). Das Bruttosozialprodukt in Deutschland nach den amtlichen Volkseinkommens- und Sozialproduktstatistiken I90I-I995. Fahrbuch für Wirtschaftsgeschichte, pp. II-37.

SPIETHOFF, A. (1924). Krisen. In Handwörterbuch der Staatswissenschaften. Jena: Fischer.

SPOERER, M. (1994). German net investment and the cumulative real wage position, I925-I929: on a premature burial of the Borchardt debate. Historical Social Research 19, pp. 26-4I.

SPOERER, M. (I997). Weimar's investment and growth record in intertemporal and international perspective. European Review of Economic History I, pp. 27I-97.

SPOERER, M. (I998). Taxes on production and on imports in Germany, I90I-I3. Fahrbuch fuer Wirtschaftsgeschichte, pp. 27I-97.

STATISTICHES REICHSAMT (I927). Wirtschaft und Stastistik 7, p. I626.

ToOzE, A. (200I). Statistics and the German State, I900-I945. In The Making of Modern Economic Knowledge. Cambridge: Cambridge University Press.

VDMA (1926a). Denkschrift über die Maschinenindustrie der Welt, bestimmt für das Komittee B des vorbereitenden Ausschusses der internationalen Wirtschaftskonferenz des Völkerbundes. Berlin: VDMA/Karl Lange.

VDMA (1926b). Die deutsche Machinenindustrie. Bericht des Vereins deutcher Maschinen-bau-Anstalten über die Fahre 1925 und 1926. Berlin: VDMA.

VDMA (1927). Statistisches Handbuch für die deutsche Maschinenindustrie 1927. Berlin: VDMA.

WAGENFÜHR, R. (1933). Die Industriewirtschaft. Entwicklungstendenzen der deutschen und internationalen Industrieproduktion I860 bis 1932. Vierteljahreshefte zur Konjunkturforschung, Sonderheft 31, pp. 3-70. 